BEHIND CLOSED DOORS 


\section{Behind Closed Doors}

\section{What Company Audit is Really About}

Vivien Beattie

Stella Fearnley

and

Richard Brandt

Foreword by Sir David Tweedie

Based on research sponsored by the Institute of Chartered Accountants in England and Wales 


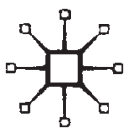

(C) Vivien Beattie, Stella Fearnley and Richard Brandt 2001 Foreword @ Sir David Tweedie 2001

All rights reserved. No reproduction, copy or transmission of this publication may be made without written permission.

No paragraph of this publication may be reproduced, copied or transmitted save with written permission or in accordance with the provisions of the Copyright, Designs and Patents Act 1988, or under the terms of any licence permitting limited copying issued by the Copyright Licensing Agency, 90 Tottenham Court Road, London W1P OLP.

Any person who does any unauthorised act in relation to this publication may be liable to criminal prosecution and civil claims for damages.

The authors have asserted their rights to be identified as the authors of this work in accordance with the Copyright, Designs and Patents Act 1988.

First published 2001 by

PALGRAVE

Houndmills, Basingstoke, Hampshire RG21 6XS and 175 Fifth Avenue, New York, N.Y. 10010

Companies and representatives throughout the world

PALGRAVE is the new global academic imprint of St. Martin's Press LLC Scholarly and Reference Division and Palgrave Publisher Ltd (formerly Macmillan Press Ltd).

ISBN 978-1-349-41115-3 ISBN 978-0-230-59941-3 (eBook)

DOI $10.1057 / 9780230599413$

This book is printed on paper suitable for recycling and made from fully managed and sustained forest sources.

A catalogue record for this book is available from the British Library.

Library of Congress Cataloging-in-Publication Data

Beattie, Vivien A.

Behind closed doors : what company audit is really about / by Vivien Beattie, Stella Fearnley, and Richard Brandt.

p. $\mathrm{cm}$.

"Based on research funded by the Institute of Chartered Accountants in England and Wales". Includes bibliographical references and index.

1. Corporations-Auditing. I. Fearnley, Stella. II. Brandt, Richard T. III. Title.

HF5686.C7 B343 2000

$657^{\prime} .45-\mathrm{dc} 21$

00-053042

$\begin{array}{rrrrrrrrrr}10 & 9 & 8 & 7 & 6 & 5 & 4 & 3 & 2 & 1 \\ 10 & 09 & 08 & 07 & 06 & 05 & 04 & 03 & 02 & 01\end{array}$

This publication is the outcome of research sponsored by the Centre for Business Performance at the Institute of Chartered Accountants in England and Wales (ICAEW). The views expressed are those of the authors and are not necessarily shared by the Institute or its Centre for Business Performance. 
I dedicate this book to my mother and father, Joyce and Bill Urquhart. In their different ways, they have both given me enormous support and encouragement throughout my life.

Vivien Beattie

We thank our families for their tolerance and support throughout the writing of this book.

Stella Fearnley and Richard Brandt 


\section{Contents}

List of Figures $\quad \mathrm{xV}$

List of Tables $\quad$ xvi

Preface xvii

Acknowledgements xviii

List of Abbreviations xix

Foreword by Sir David Tweedie $\quad$ xx

\section{PART I THE BACKGROUND}

1 Introduction and Regulatory Framework 3

1.1 What this book is about 3

1.2 Fundamental issues faced by the accountancy profession 3

1.2.1 Structural and procedural changes in the accountancy profession 3

1.2.2 Public concerns regarding the quality of financial reporting and audit 5

1.3 The regulatory framework in the UK 6

1.4 Research approach $\quad 7$

1.5 Outline of book 8

2 The Auditor-Client Relationship $\quad 10$

2.1 Overview 10

2.2 The regulatory dilemma: creative compliance 10

2.3 The auditor-client company relationship 11

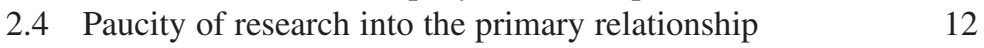

2.5 The demand for audit 13

2.6 Audit quality 14

2.7 Audit quality attributes 14

2.8 Buyer types 16

2.9 The role of commitment 17

2.10 Auditor independence 18

2.10.1 The concept and its importance 18

2.10.2 Models of independence 19

2.10.3 Studies of perceived auditor independence 20

2.10.4 Studies of actual auditor independence 23

2.10.5 The influence of the auditor's personal attributes 23 
2.11 Second partner review 25

2.12 Corporate governance and audit committees 26

2.12.1 Corporate governance 26

2.12.2 Corporate governance reporting requirements 27

2.12.3 Audit committees 29

2.12.4 Communication between external auditors and audit committees $\quad 30$

2.13 Audit effectiveness 31

3 Questionnaire Stage of Study 32

3.1 Overview 32

3.2 Methods 32

3.3 Results 33

3.4 Summary 40

PART II THE CASE STUDIES

4 Introduction to the Case Studies 43

4.1 Overview 43

4.2 Negotiation and conflict in a generic setting - theory 43

4.3 Negotiation strategies in non-audit settings - empirical studies $\quad 46$

4.4 Negotiation in audit settings - empirical studies $\quad 47$

4.5 How the case companies were selected and approached 48

4.6 Broad approach to the analysis $\quad 50$

4.7 Writing up each case (matched pair of interviews) 50

4.8 Preliminary within-case analysis: attaching labels to the key categories $\quad 51$

4.8.1 Labelling the concepts described in the stories 51

4.8.2 Preliminary analysis of the contexts 51

4.8.3 The interactions $\quad 52$

4.8.4 The outcomes 52

4.9 Within-case analysis 53

4.10 Summary of cases 53

5 Nick and Simon (NS plc) 56

5.1 Background to the case 56

5.2 The key issues for Nick and Simon 57 5.3 Interaction NS1: renegotiation of the financing
arrangements and the year-end going concern problems

5.4 Context NS(a): the changing role of the audit committee 63

5.5 Interaction NS2: the need for accounting reform in the group 
5.6 Interaction NS3: negotiations over fees 70

5.7 Analysis of general contextual factors 74

5.8 The specific interactions and their outcomes $\quad 74$

5.8.1 Interaction NS1: renegotiation of financing arrangements and year-end going concern problems

5.8.2 Interaction NS2: the need for accounting reform in the group-accounting treatment of leases $\quad 76$

5.8.3 Interaction NS3: negotiations over fees 78

$\begin{array}{lll}5.9 \text { Conclusion } & 79\end{array}$

6 Thomas and James (TJ plc) 82

6.1 Background to the case 82

6.2 The key issues for Thomas and James $\quad 83$

6.3 InteractionTJ1: stock obsolescence provisions 84

6.4 InteractionTJ2: the treatment of product development costs under FRS $3 \quad 88$

6.5 Interaction TJ3: accounting treatment of restructuring costs under FRS $3 \quad 92$

6.6 Interaction TJ4: events surrounding the sale of the group

100

6.7 Analysis of general contextual factors 102

6.8 The specific interactions and their outcomes 103

6.8.1 Interaction TJ1: stock obsolescence provisions 103

6.8.2 Interaction TJ2: treatment of product development costs under FRS $3 \quad 107$

6.8.3 Interaction TJ3: treatment of restructuring costs under FRS 3

6.8.4 Interaction TJ4: events surrounding the sale of the group

6.9 Conclusion

7 Michael and Paul (MP plc) $\quad 115$

$\begin{array}{lll}7.1 & \text { Background to the case } & 115\end{array}$

7.2 The key issues for Michael and Paul 116

7.3 Context MP(a): the group's relationship with
its auditors

7.4 Context MP(b): the role of the audit committee 119

7.5 Interaction MP1: accounting treatment and disclosures relating to an acquisition 
7.6 Interaction MP2: control and accounting problems in the group's treasury function

7.6.1 Interview evidence 132

7.7 Analysis of general contextual factors 140

7.8 The specific interactions and their outcomes 142

7.8.1 Interaction MP1: accounting issues relating to an acquisition

7.8.2 Interaction MP2: control and accounting problems in the group's treasury function $\quad 145$

7.9 Conclusion

8 Colin, Richard and Andrew (CRA plc) 151

8.1 Background to the case 151

8.2 The key issues for Colin, Richard and Andrew 152

8.3 Interactions CRA1, CRA2 and CRA3: Accounting for two acquisitions

8.3.1 Interaction CRA1: the Neweng acquisition $\quad 154$

8.3.2 Interaction CRA2: agreeing the fair values in the Cleanup acquisition

8.3.3 Interaction CRA3: accounting for depreciation on the Cleanup landfill sites

8.4 Interaction CRA4: accounting for long-term leases on fixed plant

8.5 Interaction CRA5: restructuring provisions

8.6 Context CRA(a): the working relationship between the group and its auditors

8.7 Context CRA(b): the procedure for clearing the year-end accounts and the role of the audit committee

8.8 Analysis of general contextual factors $\quad 172$

8.9 The specific interactions and their outcomes 174

8.9.1 Interaction CRA1: the Neweng acquisition 174

8.9.2 Interaction CRA2: agreeing the fair values in the Cleanup acquisition

8.9.3 Interaction CRA3: accounting for depreciation on the landfill sites

8.9.4 Interaction CRA4: accounting for long-term leases on fixed plant

8.9.5 Interaction CRA5: restructuring provisions $\quad 179$ 
9 Robert and Charles (RC plc)

9.1 Background to the case 184

9.2 The key issues for Robert and Charles 185

9.3 Interaction RC1: accounting for businesses which were to be sold on after the Coreco acquisition

9.4 Interaction RC2: agreeing the accounting treatment and the level of provisions for stock and defective products

9.5 Interaction RC3: accounting for post-acquisition reorganisation costs

9.6 Interaction $\mathrm{RC} 4$ : disclosure of reorganisation costs

9.7 Context RC(a): the composition of the audit committee and its involvement in accounting and auditing issues

9.8 Context $\mathrm{RC}(\mathrm{b})$ : the working relationships between the parties and the impact on fee negotiation 198

9.9 Analysis of general contextual factors 203

9.10 The specific interactions and their outcomes 204

9.10.1 Interaction RC1: accounting for resale of businesses acquired

9.10.2 Interaction RC2: agreeing the accounting treatment and the level of provisions for stock and defective products to be brought into the group accounts on the Coreco acquisition

9.10.3 Interaction RC3: accounting for post-acquisition reorganisation costs 208

9.10.4 Interaction RC4: disclosure of reorganisation costs

10 Dennis and Alan (DA plc)

10.1 Background to the case

10.2 The key issues for Dennis and Alan

10.3 Context DA(a): the background to the bid

10.4 Interactions DA1 and DA2: accounting for assets on disposal and acquisition of businesses 
10.4.1 Interaction DA1: accounting for assets on disposal of businesses

10.4.2 Interaction DA2: accounting for assets on acquisition of businesses

10.5 Interaction DA3: disclosure of acquisitions, disposals and bid costs under FRS 3

10.6 Interaction DA4: last-minute adjustments to the accounts

10.7 Interaction DA5: the chairman's attitude to goodwill

10.8 Interaction DA6: compliance with the Cadbury Code and other non-mandatory disclosures

10.9 Context DA(b): the role of the audit committee 233

10.10 Context DA(c): the nature of the company's relationship with its auditors

10.11 Context DA(d): non-audit services and fees

10.12 Analysis of general contextual factors

10.13 Specific interactions

10.13.1 Interaction DA1: accounting for assets on disposal of businesses

10.13.2 Interaction DA2: accounting for assets on acquisition of businesses

10.13.3 Interaction DA3: disclosure of acquisitions, disposals and bid costs under FRS 3

10.13.4 Interaction DA4: last-minute adjustments to the accounts

10.13.5 Interaction DA5: the chairman's attitude to goodwill

10.13.6 Interaction DA6: compliance with the Cadbury code and other non-mandatory disclosures

\section{PART III THE ANALYSIS AND CONCLUSIONS}

11 The Grounded Theory Process 


\section{Cross-Case Analysis and Theory Development}

12.1 Introduction

12.2 Introducing the principal categories 256

12.3 A detailed examination of each principal category 258

12.3.1 Quality of primary relationship 258

12.3.2 Company circumstances 259

12.3.3 Firm circumstances 260

12.3.4 Interaction issue 261

12.3.5 Objectives of primary parties 262

12.3.6 Key third parties 263

12.3.7 Other specific contextual factors 263

12.3.8 Interaction events 263

12.3.9 Interaction strategies 264

12.3.10 Interaction outcome 265

12.3.11 Interaction consequences 266

12.4 Grounded theory of interaction outcomes 267

Cluster 1 Good outcome, attained easily 273

Cluster 2 Good outcome, attained relatively easily/as easy as could be

Cluster 3 Good outcome, attained with difficulty

Cluster 4 Relatively good/acceptable outcome, attained easily/relatively easily $\quad 274$

Cluster 5 As good as could be, slightly difficult $\quad 274$

Cluster 6 Poor outcome, attained easily 274

Cluster 7 Poor/creative compliance outcome, attained with a degree of difficulty 274

12.5 AEP (seller) types 275

12.5.1 The 'crusader' 276

12.5.2 The 'safe pair of hands' 276

12.5.3 The 'accommodator' 276

12.5.4 The 'truster' 277

12.5.5 Other possible seller types: the 'incompetent'

12.6 Comparison with extant theory 278

13 Conclusions 279

$\begin{array}{ll}13.1 \text { Overview } & 279\end{array}$

13.2 Summary of findings 279

13.2.1 Factors which influence the company's predisposition towards earnings quality 
13.2.2 The influence of ownership structure and corporate culture on attitudes to regulatory compliance

13.2.3 Factors which influence the outcomes of financial reporting interactions

13.2.4 The effectiveness of sanctions available to FDs and AEPs and the impact of materiality on their application

13.2.5 Partner types and quality control in audit firms

13.3 The policy implications of our findings

13.3.1 The auditor's influence on the quality of financial reporting

13.3.2 The key to auditor independence

13.3.3 Creative compliance

13.3.4 Substance and form of corporate governance

13.4 Proposals and issues for regulators and audit firms to consider

\subsubsection{Regulators}

13.4.2 Audit firms 288

13.5 Implications for future research 290

13.5.1 Further verification of grounded theory 290

13.5.2 Further development of grounded theory 291

13.5.3 Implications for related areas of research 291

13.5.4 In closing ... 292

Bibliography $\quad 294$

Index $\quad 302$ 


\section{List of Figures}

$\begin{array}{lll}5.1 & \text { Nick and Simon: general context for interactions } & 75\end{array}$

5.2 Treatment of leases (NS2) 77

6.1 Thomas and James: general context for interactions 104

6.2 Stock obsolescence provisions interaction stages 1 and 2 (TJ1) 105

6.3 Product development costs interaction (TJ2) 108

6.4 Restructuring costs interaction (TJ3) 110

7.1 Michael and Paul: general context for interactions 141

7.2(a) Acquisition and accounting interaction (MP1) stage 1: negotiation of numbers

7.2(b) Acquisition and accounting interaction (MP1) stage 2: wording of audit qualification

7.3 Control and accounting issues re treasury function interaction (MP2)

8.1 Colin, Richard and Andrew: general context for interactions

8.2 Cleanup acquisition interaction (CRA2) 176

$\begin{array}{lll}8.3 & \text { Depreciation policy interaction (CRA3) } & 178\end{array}$

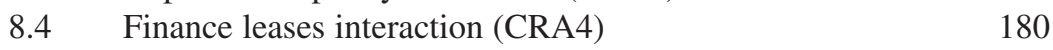

8.5 Restructuring provisions interaction (CRA5) 181

9.1 Robert and Charles: general context for interactions 205

9.2 Accounting for resale of businesses acquired interaction $(\mathrm{RC} 1)$

9.3 Accounting for stock and defective products on acquisition (RC2)

10.1 Dennis and Alan: general context for interactions 241

10.2 Accounting for assets on acquisition of businesses interaction (DA2)

10.3 Chairman's attitude to goodwill interaction (DA5) 246

11.1 The grounded theory research process 255

12.1 Principal analytical categories 257

12.2 Key links between context, strategy and outcome 267

12.3 Relationships between contextual factors and outcome 271

12.4 Visual representation of interaction outcomes in two dimensions, showing seven clusters $\quad 272$

12.5 A hierarchy of AEP (seller) types and their characteristics 276 


\section{List of Tables}

2.1 Key characteristics of buyer types 17

3.1 Ten most frequently discussed issues 34

3.2 Ten most frequently negotiated issues 35

3.3 Frequency of changes to accounting numbers and disclosures resulting from discussion and negotiation $\quad 37$

4.1 The developmental process in negotiation 45

4.2 Overview of cases 54

6.1 Restructuring costs interaction (TJ3): key stages and intervening events 109

7.1 Acquisition accounting interaction (MP1): key stages 142

7.2 Control and accounting issues re treasury function interaction (MP2): key stages and intervening events $\quad 147$

12.1 Quality of primary relationship 258

12.2 Company circumstances of relevance to interactions 259

12.3 Firm circumstances 261

12.4 Interaction issue 262

12.5 Objectives of individual parties 262

12.6 Key third parties 263

12.7 Other specific contextual factors 264

12.8 Interaction events 264

12.9 Interaction strategies $\quad 265$

12.10 Interaction outcome 266

12.11 Interaction consequences 266

12.12 Cross-case analysis of critical contextual factors, strategies adopted and financial reporting outcome dimensions 


\section{Preface}

The audit of public companies is a very private activity. All that the outsider is aware of is the existence of a (usually clean) external audit report that says that the financial statements represent a true and fair view. Periodically there is a highly publicised company collapse and there are allegations of audit failure. This book uncovers, for the first time, what really goes on behind the closed corporate doors. It reveals the true extent of the effort that goes into finalising the financial statements of a public listed company and the generally high level of expertise and integrity within the UK auditing profession.

It does this by identifying a varied group of six UK public companies that had recently experienced audit interactions involving significant accounting issues. Matched interviews with both the finance director and the audit engagement partner were conducted and analysed using grounded theory methods. This method of analysis is designed to establish the factors that influence the nature and outcome of these audit interactions. It supports a rich understanding of the principal parties and their motivations, their relationship, the contextual factors that influence the interaction process and the strategies adopted, and the critical factors that determine the quality of the financial reporting outcome and the ease with which it is achieved.

'Earnings quality' may be a relatively recent term, but concern with this issue has been a central theme for the accountancy profession for decades. The impact that the auditor has on earnings quality is also central and associated with this are well-publicised concerns regarding auditor independence. The findings of this book inform both debates. 


\section{Acknowledgements}

The financial support of the Centre for Business Performance of the Institute of Chartered Accountants in England and Wales is gratefully acknowledged. We would also like to thank the twelve participants who were willing to talk to us about their audit experiences so frankly.

V.B.

S.F.

R.B. 


\section{List of Abbreviations}

$\begin{array}{ll}\text { AEP } & \text { Audit Engagement Partner } \\ \text { AICPA } & \text { American Institute of Certified Public Accountants } \\ \text { APB } & \text { Auditing Practices Board } \\ \text { ASB } & \text { Accounting Standards Board } \\ \text { CAJEC } & \text { Chartered Accountants Joint Ethics Committee } \\ \text { CCAB } & \text { Combined Committee of Accounting Bodies } \\ \text { CEO } & \text { Chief Executive Officer } \\ \text { DTI } & \text { Department of Trade and Industry } \\ \text { EC } & \text { European Community or European Commission } \\ \text { EU } & \text { European Union } \\ \text { FD } & \text { Finance Director } \\ \text { FEE } & \text { Fédération des Experts Comptables Européens } \\ \text { FRC } & \text { Financial Reporting Council } \\ \text { FRRP } & \text { Financial Reporting Review Panel } \\ \text { FRS } & \text { Financial Reporting Standard } \\ \text { ICAEW } & \text { Institute of Chartered Accountants in England and Wales } \\ \text { ISB } & \text { Independence Standards Board } \\ \text { MAS } & \text { Management Advisory Services } \\ \text { NAS } & \text { Non-Audit Services } \\ \text { NASD } & \text { National Association of Securities Dealers } \\ \text { NED } & \text { Non-Executive Director } \\ \text { NYSE } & \text { New York Stock Exchange } \\ \text { POB } & \text { Public Oversight Board } \\ \text { PwC } & \text { PricewaterhouseCoopers } \\ \text { SEC } & \text { Securities and Exchange Commission } \\ \text { SECPS } & \text { Securities and Exchange Commission Practice Section } \\ \text { SPR } & \text { Second Partner Review } \\ \text { UITF } & \text { Urgent Issues Task Force } \\ & \end{array}$




\section{Foreword}

In a speech (September 2000) to the National Association of State Boards of Accountancy, Chairman Arthur Levitt, of the Securities and Exchange Commission quoted from an author of the 1960s:

'accountants began to take on the corporate mentality, to think of themselves no longer as independent, critical, perhaps even judicial examiners, but as part of management, members of the corporate "team" ... "It was a question of role definition." Accountancy was losing its soul, then, the way so many souls are lost - by definition and by degree.'

Chairman Levitt concluded:

'I believe the time has come for the profession's own broader membership ... to stand up and take back what some are trying to take from them: the pride and privilege of serving the American public and its investors as the most rigorous, objective, and independent accountants in the world; it's time that the profession's own take back the cause and determine the course; it's time that the profession's own take back the spirit of the franchise that America's investors bestowed upon them long ago.'

The decline in the standard of British auditing was probably most marked in the mid to late-1980s. Schemes were developed, many in the City of London, which, while not contrary to the (then) accounting standards or the law, were at the edge, and some of us would say beyond, the limits of acceptability. In the absence of a strong accounting standards regime the true and fair view proved to be a double edged sword. It consists not only of accounting standards but also accepted practice. Some of the accounting schemes were accepted by one or two major firms of auditors and consequently moved within the corpus of practice covered by true and fair. From that moment auditors were powerless to reject the schemes by qualifying the accounts. This situation, in part, led ultimately to the formation of the Financial Reporting Council and its two attendant bodies, the Accounting Standards Board (which in turn created the Urgent Issues Task Force) and the Financial Reporting Review Panel. What was needed, however, was a sea-change in the attitude of the profession. As Mr Levitt has put it, it was time that the profession's own took back the cause. 
The will for change in the 1990s was manifest. The Board would not have succeeded in its programme of reform had it not been backed enthusiastically by auditors, finance directors and users of accounts. While the Auditing Practices Board set out to define best practice, the new generation of auditors developed more backbone and began to question practices that previously would have been accepted.

This fascinating book pulls aside the veil over the audit process and shows to those who have not been involved the difference between good and bad auditors. It shows in its case studies the highly competent auditor imbued with integrity (deemed to be the 'crusader' or the 'safe pair of hands'). In contrast, it reveals 'the accommodator' and the 'truster' - the former bending to the client's wishes, forgetting that the auditor's role is to serve the public not management's interest, the latter tending to leave his client alone assuming all will be well. Fortunately, evidence was not presented of the incompetent or rogue auditor, although the accommodator came very close.

The cases highlight, too, the need for accounting firms to match engagement partners with management. It is senseless sending along a newly qualified partner to deal with a highly experienced senior finance director who could set out to intimidate the younger accountant.

Questions are also raised about the appointment of auditors and the use by finance directors of the threat of putting the audit out to tender. This, of course, raises issues of corporate governance and whether executive directors should have the power to appoint or fire auditors.

The case studies are anonymous - which is as well for the auditor who allowed overvalued stock to be written down over three years - for goodness sake! In better cases, however, it reveals the standards to which all auditors should aspire. The encouraging conclusion is that, despite the exceptions, both the profession and the quality of its audits are fundamentally sound.

This book will be fascinating for those involved in audit and who know the dynamics of the meetings between company management and auditor. It should be a stern lesson for those auditors who still do not reach the required level of independence from management. For those to whom the audit is something of a mystery, it shows how a good audit and a good auditor is a vital safeguard in ensuring transparency and investor protection.

I was encouraged by this readable study. It shows the audit profession in a much stronger position than it was ten years ago and clearly on the way up. For those auditors who do not match the best, the appropriate standard is clearly visible. Independence from management can 
be achieved, it should be achieved, and, for the sake of the auditing profession, it must be achieved or the societal purpose of the audit is lost and with it the accounting profession.

September 2000

SIR DAVID TwEEDIE

Chairman of the Accounting Standards Board

London 